\title{
5 \\ THE TELESCOPE AND THE TINDERBOX: REDISCOVERING LA PÉROUSE IN THE NORTH PACIFIC
}

It was late on a summer's day, and the wind had dropped, when the two ships entered the bay. They remained quite still, some distance offshore from the place where the river flowed into the sea. The villagers of Tomarioro had seen foreign vessels, of course. The canoes of the mainland people whom they knew as Sandā were regular visitors: one had arrived just a few days earlier. ${ }^{1}$ The junks of Sisam (Japanese) from the south occasionally sailed close to the shore, and there were darker stories of other, unknown visitors who came from the north and west. ${ }^{2}$ But these two ships were unlike anything they had seen before.

1 Except where otherwise indicated, the details in this account (including the presence of the Sandā canoe) are derived from Jean-François de Galaup de La Pérouse, The Journal of Jean-François de Galaup de La Pérouse, trans. and ed. John Dunmore, vol. 2 (London: The Hakluyt Society, 1995), pp. 286-95; 'Sandä' or 'Santa' was the Ainu word used to refer to traders from the Amur river region; see Kojima Kyōko, '18, 19 Seiki ni Okeru Karafuto no Jūmin: "Santan” o Megutte', in Minzoku Sesshoku: Kita no shiten kara, ed. Hoppō Gengo Bunka Kenkyūkai (Tokyo: Rokkō Shuppan, 1989), pp. 31-47, particularly p. 35.

2 On Manchu officials and other visitors to the west coast of Sakhalin, see Mamiya Rinzō, 'Kita Ezo Zusetsu or a Description of the Island of Northern Yezo by Mamiya Rinsō', trans. John A Harrison, Proceedings of the American Philosophical Society 99, no. 2 (1955): pp. 93-117, particularly pp. 116-17, original published in 1855; Mogami Tokunai, 'Ezo Sōshi Gohen', in Ezo Sōshi, by Mogami Tokunai, ed. Yoshida Tsunekichi (Tokyo: Jiji Tsūshinsha, 1965), pp. 189-90. 
One by one, small boats crossed the water between the two ships and the shore, and by the time the villagers had returned from fishing, a group of strangers had gathered on the beach. They spoke a language that no one understood, but they seemed harmless, and left gifts of axes, pieces of metal, beads and cloth at the entrance to one of the village houses. The next morning, the ships were still there, and the strangers came back to the shore. As though performing magic, out of their bags they produced a seemingly endless stream of objects: lumps of precious metal; pieces of cotton and silk; coloured glass rings; red, white and yellow feathers; flasks of vile-smelling liquid ... ${ }^{3}$ Once again, they set out their gifts and began to speak in their unknown language. All the men of Tomarioro gathered round, and tried to help the visitors by pointing out different objects boat, house, sun, and so on - and saying the word for each object. The strangers appeared to understand, for they took out paper and writing implements and tried to write each word down.

Then, through pointing and sign language, they gestured that they wanted to go to land of the Manchus: a promising sign that, having left their gifts, they would soon sail away. One of the henke (elders) drew a map for them on the sand, showing the coastline and the way to the mouth of the Segalien River. The strangers recognised the name of the river, and were delighted by the map, but by now the tide was coming in and washing away the traces on the sand, so a young man took a piece of paper from the visitors and drew the map for them again, using sign language to add information about the distance to each stopping point and the depth of the sea along the coast. ${ }^{4}$

The strangers remained all day, poking and staring at everything, and always making notes on paper, but they did no serious damage. There were just a few worrying moments when one of them produced some strange instruments and tried to press them against the body of an henke, to measure the size of his torso. The henke recoiled, gesturing his refusal with his hands, and the stranger understood and put the instruments away.

3 See 'Catalogue of Goods and Merchandize Put on Board the Vessels Under the Order of Mr. de la Pérouse, for the Purpose of Barter and Making Presents', in Jean-François de Galaup de La Pérouse, A Voyage Round the World Performed in the Years 1785, 1786, 1787 and 1788 by the Boussole and the Astrolabe, vol. 1, 1969 reprint (Amsterdam: N. Israel; New York: Da Capo Press, 1969), pp. 182-86, doi.org/10.1017/cbo9781139056519.004; also La Pérouse, Journal, p. 294.

4 La Pérouse, Journal, pp. 289-91. 
Next morning, soon after dawn, the two strange ships sailed out of the bay and were never seen again. But after that, foreign ships came more frequently, some from the south and some from the west. The Sisam started to build houses on the shore and catch fish in vast nets, and then the Nuća (Russians) came with cows and pigs, cutting the forests and killing the dogs that were the Tomarioro villagers' most precious possessions. The people of the villages up and down the coast began to fall ill and die of strange diseases. The landscape changed, and language with it. The villagers of Tomarioro became Russian, and then Japanese. Four generations on, their descendants no longer remembered the two tall ships and strangers with their bazaar of gifts. All they remembered were the dark stories of dangerous white-skinned people who had hideous faces and held their heads in a strange way. ${ }^{6}$ Then a huge Japanese pulp mill was built on the banks of the river, polluting the waters of Tomarioro Bay; and then the Russians came back again ...

Today, the descendants of the Tomarioro villagers, if any survive, are far away in Hokkaido. There are few, if any, Ainu/Enchiw ${ }^{7}$ left in the little Russian town of Tomari today. ${ }^{8}$

\section{The Floating Enlightenment}

The story I have just retold is a famous one: it is the tale of the arrival in July 1787 of French explorer Jean-François de Galaup de La Pérouse and his two ships, the Boussole and the Astrolabe on the shores of the island of Sakhalin, at the place that La Pérouse named De Langle Bay. This is a story that has been recounted in many ways, for there is something strangely compelling about narrative of the La Pérouse voyage.

5 See Alfred F Madjewicz, ed., The Collected Works of Bronislaw Pitsudski, vol. 3, Materials for the Study of the Ainu Language and Folklore 2 (Berlin: Mouton de Gruyter, 2004), p. 214.

6 Bronislaw Piłsudski, who investigated the story in the first years of the twentieth century, wrote: 'I knew of the Sakhalin visits of La Pérouse and Khruzenstern, and kept enquiring about them with many elderly Ainu. Nobody, however, was in a position to quote descriptions of just those encounters. Remembered were certain hostile encounters probably with some seamen from Kamchatka who touched the Sakhalin shores, and tales about them later assumed the shape of obscure legends about terrifying men with ugly faces and a strange, non-Ainu, way of carrying one's head.' See Madjewicz, Collected Works of Bronislaw Pitsudski, p. 227.

7 Sakhalin Ainu used both the 'Ainu' and the word 'Enchiw' to describe themselves. The descendants of Sakhalin Ainu living in Japan today generally use the word Enchiw as their preferred term.

8 See, for example, Tjeerd de Graaf, 'The Ethnolinguistic Situation on the Island of Sakhalin', in Ethnic Minorities in Sakhalin, ed. Kyoko Murasaki (Yokohama: Yokohama Kokuritsu Daigaku Education Department, 1993), pp. 13-29, particularly p. 15. 
Not simply a European journey in search of the contours of distant lands, the expedition was a floating pageant of the Enlightenment. La Pérouse's crew set off around the world with their ships filled to the gunwales with the latest scientific instruments and learned texts. They had three types of telescope, hydrometers, aerometers, mathematical instruments, 'a great number of barometers, thermometers, and hygrometers, of different kinds, for various experiments', a reverberatory furnace, a portable mineralogical chest and veritable cocktail cabinet of chemicals, as well as an extraordinary emporium of gifts, which could be used to assess the cultural inclinations of the various 'natives' they met along the way.' Tracing this seaborne microcosm of Enlightenment Europe as it tracked its way slowly across the Atlantic, round Cape Horn, to Alaska and California, to Macao, Manila, Sakhalin, Kamchatka, Samoa, Australia, and then into oblivion, we can observe the sparks generated as it reacted with a multitude of differing societies along the route.

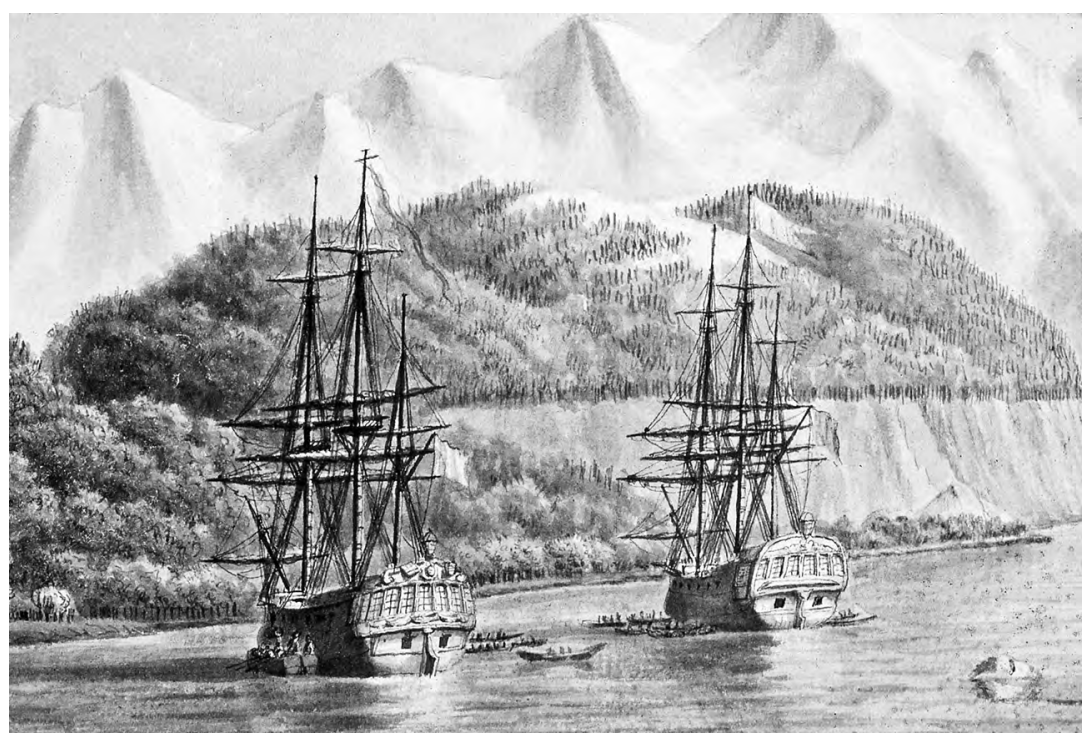

Figure 5.1. The Astrolabe and Boussole at anchor off the island of Maui.

Source: Wikimedia commons, public domain.

9 'Summary of the Instruments of Astronomy, Navigation, Natural Philosophy, Chemistry, etc. etc. for the Use of the Men of Science and Artists Employed in the Voyage of Discovery', in La Pérouse, Voyage, pp. 182-86. 


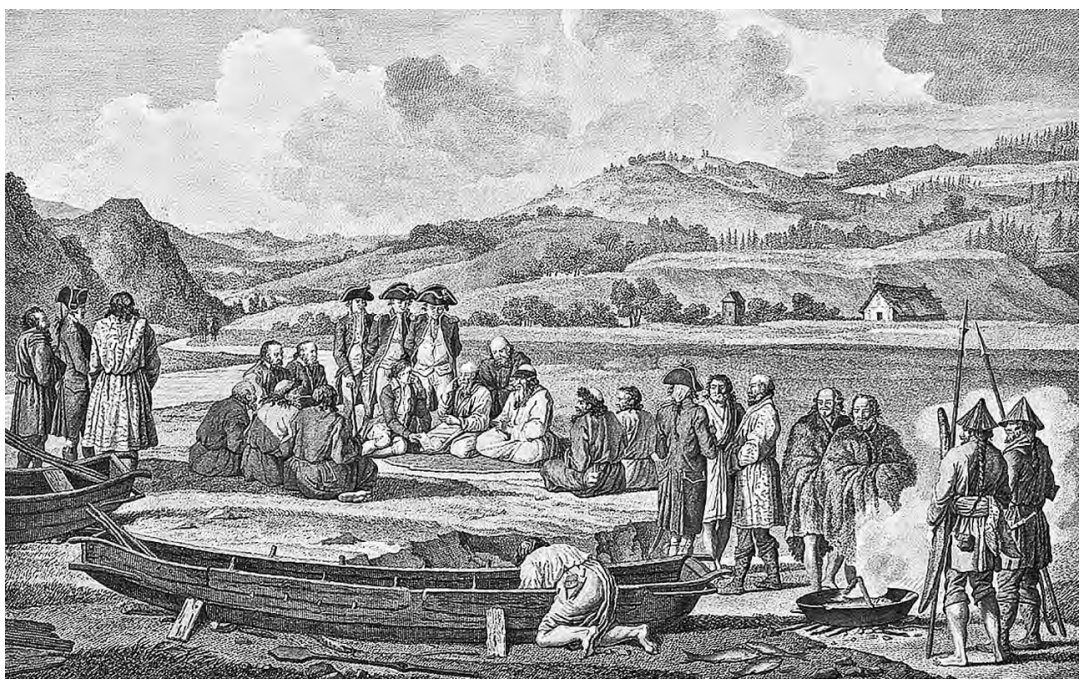

Figure 5.2. People of Tomarioro as seen by La Pérouse's expedition.

Source: Illustration by Gaspard de Vancy and LJ Cathelin from Jean-François de Galaup de La Pérouse, Atlas du Voyage de La Pérouse autour du Monde (Paris: 1797).

The mystery and tragedy of its ending makes the story more compelling still. The ships sailed into the unknown, and it took more than two centuries to unravel the details of their fate. The voyage ended in shipwreck in the South Pacific, the marvels of Enlightenment science scattered like broken toys across Vanikoro reef. The men who had set off to probe the mysteries of global geography and humanity spent their final months and years struggling unsuccessfully for bare physical survival, overwhelmed by the forces of alien culture and nature. ${ }^{10}$

But it is the moments of direct encounter in their journey to the Pacific that particularly stir the imagination: those moments when an islander of Sakhalin or Hawai $i$ looks into the eyes of a man from France, and each wonders if he can trust the other. In recent years, the meeting on the beach between La Pérouse and the people of 'De Langle Bay' (Tomarioro) - where the native elder drew a map of the region on the sand, and the younger man then copied it onto paper for the explorers - has in particular been read as an encounter replete with the meaning of Enlightenment knowledge. For sociologist of science Bruno Latour, this coming together of native map-maker and European cartographer provides the key to explaining what is distinctive about modern science.

10 John Dunmore, Where Fate Beckons: The Life of Jean-François de Galaup de la Pérouse (Sydney: ABC Books, 2006), pp. 259-64. 
Latour acknowledges the mapping skills of the De Langle Bay natives (whom he describes, with a surprisingly cavalier approach to geography and ethnography, as 'Chinese'). There is nothing in the mapping itself, he suggests, to separate the Sakhalin 'Chinese' from the European explorer. What differentiates them is the fact that the explorers form part of a network of Enlightenment knowledge, in which geographical, biological, mechanical and other know-how can all be represented on paper in schematic form. These schematic representations - charts, diagrams, architectural and mechanical blueprints, and so on - are mobile: they can be taken anywhere. Because they are standardised, they can be compared, superimposed and combined. The French expedition can turn knowledge acquired from the local people into mobile inscriptions to be brought back to the European centre, adding to the growing store of Western scientific knowledge, and thus of Western power. ${ }^{11}$

In Latour's telling of the story, the 'bringing back' is crucial.

The Chinese have lived here as long as one can remember whereas the French fleet remains with them for a day. These families of Chinese, as far as one can tell, will remain around for years, maybe centuries; L'Astrolabe and La Boussole have to reach Russia before the end of summer. ${ }^{12}$

The explorers' haste reflects the fact that they are 'not so much interested in this place as they are in bringing this place back, first to their ship and then to Versailles'. ${ }^{13}$ The visual inscriptions of Enlightenment science are mobile, whereas the things they inscribe - 'Chinese, planets, microbes' - are not. ${ }^{14}$ 'Bringing back' is the key that turns knowledge into power. In a process that mirrors the accumulation of capital in the metropolises of Europe, this results in a steady accumulation of knowledge at the centre - one map superimposed upon another until the whole globe is known. So the European explorers, who on the first voyage are weak and at the

11 Bruno Latour, Science in Action: How to Follow Scientists and Engineers Through Society (Cambridge, Mass.: Harvard University Press, 1987), ch. 6; Bruno Latour, 'Visualization and Cognition: Drawing Things Together', in Knowledge and Society: Studies in the Sociology of Culture Past and Present, ed. Henricka Kuklick and Elizabeth Long, vol. 6 (Greenwich, CT: JAI Press, 1986), pp. 1-40.

12 Latour, Science in Action, p. 217.

13 Latour, Science in Action, p. 217.

14 Latour, 'Visualization and Cognition', p. 18. 
mercy of the native, gradually become strong, and the cartographer who remains fixed in the centre of the Enlightenment world, reading and studying the maps, becomes the most powerful of all. ${ }^{15}$

Latour views the scene on the beach at Tomarioro as through a telescope from the metropolis. Indeed, his depiction of the 'Chinese' islanders is more distant and exoticised than La Pérouse's own account. (La Pérouse distinguishes the Tomarioro villagers from Chinese, and makes clear that they are linked into their own networks of trade and travel.) Michael Bravo, drawing on but revising Latour, retells the story of La Pérouse and the Tomarioro map-makers in ethnographic terms and from the perspective of the field encounter'. ${ }^{16}$ Rather than isolating the mapdrawing episode, Bravo places it in the broader context of La Pérouse's circuitous journey round the Amur-Okhotsk region - the region from the north-eastern stretch of the Asian mainland in the west, to the shores of Sakhalin, past the north of Hokkaido, and to the Kurile archipelago, and the Kamchatka Peninsula in the east. It is only by looking in detail at the dynamics of various encounters along the route, Bravo suggests, that we can understand how knowledge is 'displaced' from the local informant to the explorer, and how 'enlightened navigators impose or distill time and space in the course of their encounters'. ${ }^{17}$

In this retelling of the narrative, La Pérouse does not arrive with fully formed scientific constructs for understanding the world already charted in his brain. His expedition's ethnographic classifications emerge only from a gradual process of description and comparison - a tentative generation of categories and boundaries. A key element in this 'ethnographic navigation' is the 'geographic gift'. ${ }^{18}$ The process of creating ethnographic knowledge begins with the giving of gifts to the locals - an act designed to evoke words of response from the 'native'. This opens the way to a search for forms of commensurable language, which in turn will make it possible for the explorers to gather the elements that enable them to draw ethnographic comparisons and boundaries.

15 Latour, Science in Action, pp. 219-24.

16 Michael Bravo, 'Ethnographic Navigation and the Geographical Gift', in Geography and Enlightenment, ed. David N Livingston and Charles WJ Withers (Chicago: University of Chicago Press, 1999), pp. 199-235, quotation from p. 205.

17 Bravo, 'Ethnographic Navigation', p. 203.

18 Bravo, 'Ethnographic Navigation', p. 204. 


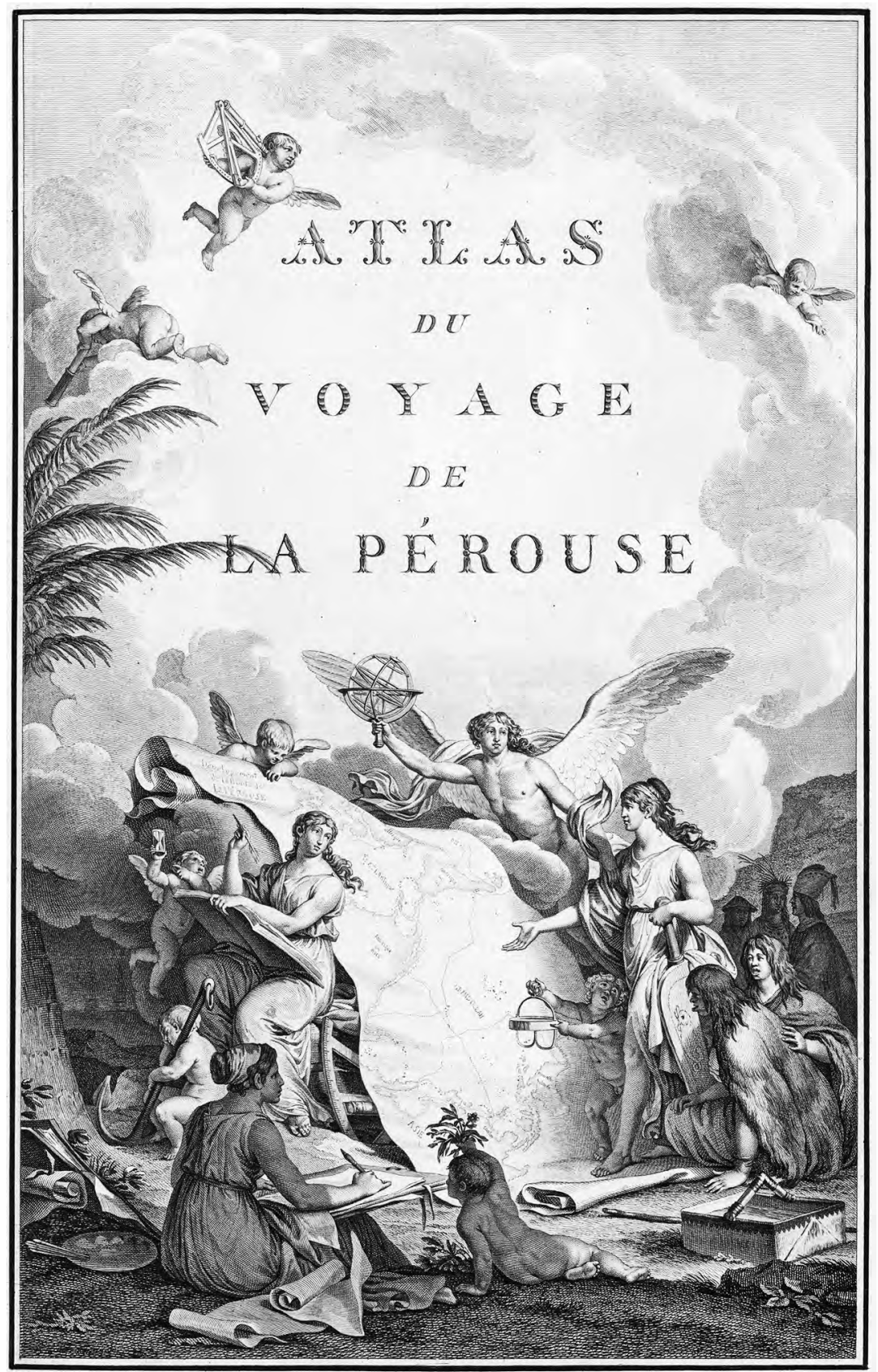

Figure 5.3. Frontispiece from La Pérouse's atlas.

Source: Image by JM Moreau and P Trière, from Jean-François de Galaup de La Pérouse, Atlas du Voyage de La Pérouse autour du Monde (Paris: 1797). 
Bravo's view from 'the field' is more nuanced and less schematic than Latour's telescopic view from the metropolis. It recognises the complex interactions between the Tomarioro villagers and other neighbouring societies, including those of the Amur region and Japan. Bravo correctly identifies the villagers as Ainu rather than as 'Chinese', and reminds us that we should not 'ignore the importance of trade, travel and migration in their ways of life'. ${ }^{19}$ His account, though, conveys some misconceptions of its own. He identifies the 'Orotchy' people of the place La Pérouse named 'De Castries Bay' with the reindeer-herding Uilta people of Sakhalin (known to their neighbours as 'Orok'), and he draws conclusions about the Orotchy way of life based on observations of the Uilta relationship with reindeer. But the people whom La Pérouse called Orotchy were clearly a different group from the Sakhalin Uilta, and did not herd reindeer. Bravo also depicts the Ainu communities that La Pérouse visited as being subject to a mixture of government assimilationism and merchant exploitation from Japan, but this is anachronistic. ${ }^{20}$ At the time of La Pérouse's arrival, the creeping spread of Japanese mercantile and fishing interests had barely reached the areas that he visited. Though officials and fishermen from Matsumae Domain, and even officials of the Japanese shogunate, had travelled to Sakhalin, the first permanent Japanese fishing base, in the village of Shiranushi at the far south of the island, was not established until $1790 .^{21}$

What is particularly fascinating about La Pérouse's account, indeed, is the fact that it captures a glimpse of western Sakhalin and the Lower Amur on the eve of momentous historical change. In 1787, Russian and Japanese nation/empire-building was seeping into the region from north and south like a relentlessly rising tide, but there was still a space between, in which multiple connections among the newly arriving powers and longer established communities were being forged. This space between allowed room for the presence of the Chinese empire, whose force continued to be faintly felt on the western shores of Sakhalin as late as the 1780s, but which was soon to be driven out of the Amur-Okhotsk region.

19 Bravo, 'Ethnographic Navigation', p. 207.

20 Bravo, 'Ethnographic Navigation', pp. 208-09.

21 See Hora Tomio, Karafuto shi Kenkyū: Karafuto to Santan (Tokyo: Shinjusha, 1956), p. 66; Akizuki Toshiyuki, Nichirō Kankei to Saharintō: Bakumatsu Meiji Shoki no Ryödo Mondai (Tokyo: Chikuma Shobō, 1994), p. 36; on Japanese settlement in Karafuto, see also David L Howell, Capitalism from Within: Economy, Society and the State in a Japanese Fishery (Berkeley and London: University of California Press, 1995), pp. 40-41. 
Latour's and Bravo's interpretations of La Pérouse's visit to Sakhalin and the Amur have been widely cited by other scholars, ${ }^{22}$ and it is important both to acknowledge the value of their visions of the knowledge-creating process, and to address the inaccuracies of detail that their accounts perpetuate. But the more important point is that the perspective from the metropolis and the perspective from the field leave one crucial perspective still invisible: the perspective from the region explored by La Pérouse, seen not as a 'field of enquiry' but as a place in its own right - a place with its own past, present and future. I am not, of course, suggesting that we can actually find out exactly how the Ainu of Tomarioro and other Sakhalin villages saw the arrival of La Pérouse's ships. The account with which I began this chapter is obviously an act of imagination, though one based as closely as possible on the written record. But what I do want to suggest is that traces in written and other records provide a wealth of information on the history of this region in the 1780 s, including some elusive but intriguing glimpses of indigenous perspectives on the coming of Europeans; and if we see La Pérouse's voyage as an event in that regional history, as well as an event in the history of the European Enlightenment, several neglected but significant dimensions of the formation of modern knowledge become visible.

The view from the region allows us to compare diverse but roughly contemporary descriptions of the same place. This in turn enables us to develop an imbricated history of the interactions between diverse groups, which in turn sheds some important light on the processes of communication and miscommunication between Enlightenment explorers and local people. Looking at La Pérouse's voyage within the context of the late eighteenth-century history of the Amur-Okhotsk region makes it easier to see the source of one of the explorer's most significant cartographical mistakes - and understanding processes of miscommunication and the making of scientific mistakes is, I shall argue, as important as (indeed, an inseparable part of) understanding processes

22 Works which cite both Latour's and Bravo's versions of the map drawing story include: David N Livingstone, Putting Science in its Place: Geographies of Scientific Knowledge (Chicago: University of Chicago Press, 2003); Brett L Walker, 'Mamiya Rinzō and the Japanese Exploration of Sakhalin Island: Geography and Empire', Journal of Historical Geography 33, no. 2 (2007): pp. 283-313, doi.org/ 10.1016/j.jhg.2006.05.007; James Delbourgo and Nicholas Dew, 'Introduction: The Far Side of the Ocean', in Science and Empire in the Atlantic World, ed. James Delbourgo and Nicholas Dew (London and New York: Routledge, 2008), pp. 1-28; Simon Schaffer, 'The Asiatic Enlightenments of British Astronomy', in Brokered Worlds: Go-Betweens and Global Intelligence, 1770-1820, ed. Simon Schaffer, Lissa Roberts, Kapil Raj and James Delbourgo (Sagamore Beach: Science History Publications, 2009), pp. $49-104$. 
of communication and the discovery of scientific truth. A perspective from the region also reminds us that European explorers were not only observers but also observed. This complicates our perception of the flows of information that generated the modern knowledge system. When we probe the multidirectional, overlapping flows of knowledge about 'alien' people and places that intersected in the Amur-Okhotsk region in the eighteenth century, it becomes more difficult to accept simple visions of a scientific circuit that endlessly sucks global knowledge into the academies and laboratories of enlightened Europe. Instead, the creation of modern cartographic and ethnographic knowledge of the world begins to look more untidy and multipolar, and the relationship between science and empire more random, contingent and violent.

\section{From the Amur to the Okhotsk: Retracing La Pérouse's Route}

Let us begin, then, by retracing the course of the Astrolabe and the Boussole through the northern Pacific between July and August 1787, placing their journey more firmly in the historical landscape of the region itself. The two ships arrived from the south: they had left Manila in April, and sailed past the Ryukyu Kingdom (now known as Okinawa) and the west coast of Japan and Hokkaido, before arriving in the Tartar Strait in July. Off the southern islands of the Ryukyus, La Pérouse observed the local people in boats, labelled them 'Kumi' and depicted them as a group intermediate to the Japanese and Chinese; a rather astute observation, as the Ryukyu Kingdom was at that time semi-independent, but paid tribute both to the Chinese empire and (via the Domain of Satsuma) to Japan.

La Pérouse did not attempt to land on the coast of Japan. Advisedly, he was much more afraid of the Japanese than of the small societies to their north, since the Japanese shogunate exerted very tight control on the arrival of foreign vessels, and an unauthorised landing might have been severely punished. For the same reason, he was wary of landing on the shores of Hokkaido (referred to in La Pérouse's journal as Yeso). His first landfall in the region was at the place he named De Langle Bay, after the captain of the Astrolabe. From the coordinates given by La Pérouse and later travellers, we can identify this as the Ainu village of Tomarioro, which, appropriately enough, meant 'anchorage' or 'place for stopping 
boats'. ${ }^{23}$ Tomarioro was a relatively small village, less significant in the life of the region than settlements like Nayoro, some 10 miles to the north, or Ushiyoro, which La Pérouse later visited and named D'Estin Bay. The Ainu of Tomarioro and surrounding areas fished, gathered food plants and hunted for various animals in the nearby forests, and kept dogs (who assisted with hunting and fishing, pulled boats and sleds). La Pérouse noticed signs of trade between the village and the Asian mainland, including the presence of two visitors from the mainland, who had (he guessed) come to buy fish.

In fact, the coastal villages of Sakhalin were engaged in a complex web of trade routes that spread in many directions. Ainu from Hokkaido sometimes travelled to Sakhalin, and the Nivkh and Uilta people who lived in the north and east of the island traded with the Ainu who lived in the south. Members of the various mainland communities who lived along the lower reaches of the Amur (and whom the Ainu collectively referred to as 'Sandä' or 'Santa' and the Japanese as 'Santan') travelled to Sakhalin to trade furs for goods that reached the region both from Japan in the south and China in the west. Chinese brocades were traded via the Amur to the Ainu of Sakhalin and Hokkaido, and some even reached the metropolitan centres of Japan, where they were known as 'Ezo brocade' (Ezo nishiki). Nivkh populations lived not only in northern Sakhalin but also on the Lower Amur, and regularly travelled back and forth between mainland and island. Ainu from Sakhalin also travelled to the mainland and down the Amur to the Manchu trading post of Deren. ${ }^{24}$ This helps to explain the ease with which the Tomarioro villagers were able to draw maps of the western Sakhalin coast and the Amur (Segalien) River for La Pérouse and his crew.

23 On the location of De Langle Bay, see also EG Ravenstein, The Russians on the Amur (London: Trübner and Co., 1861), p. 269. La Pérouse's measurements of longitude in the Amur-Okhotsk region are known to have been inaccurate by about 1 degree, but his measurements of latitude were generally accurate; see La Pérouse, Journal, p. 305.

24 For further discussion, see Tessa Morris-Suzuki, Henkyō kara Nagameru: Ainu ga Keiken suru Kindai (Tokyo: Misuzu Shobō, 2001); see also Hokkaidō Kaitaku Kinenkan, ed., Santan Kōeki to Ezo Nishiki (Sapporo: Hokkaidō Kaitaku Kinenkan, 1996); Hora Tomio, Karafuto shi Kenkyū; Kojima, '18, 19 Seiki ni Okeru Karafuto no Jūmin'. 


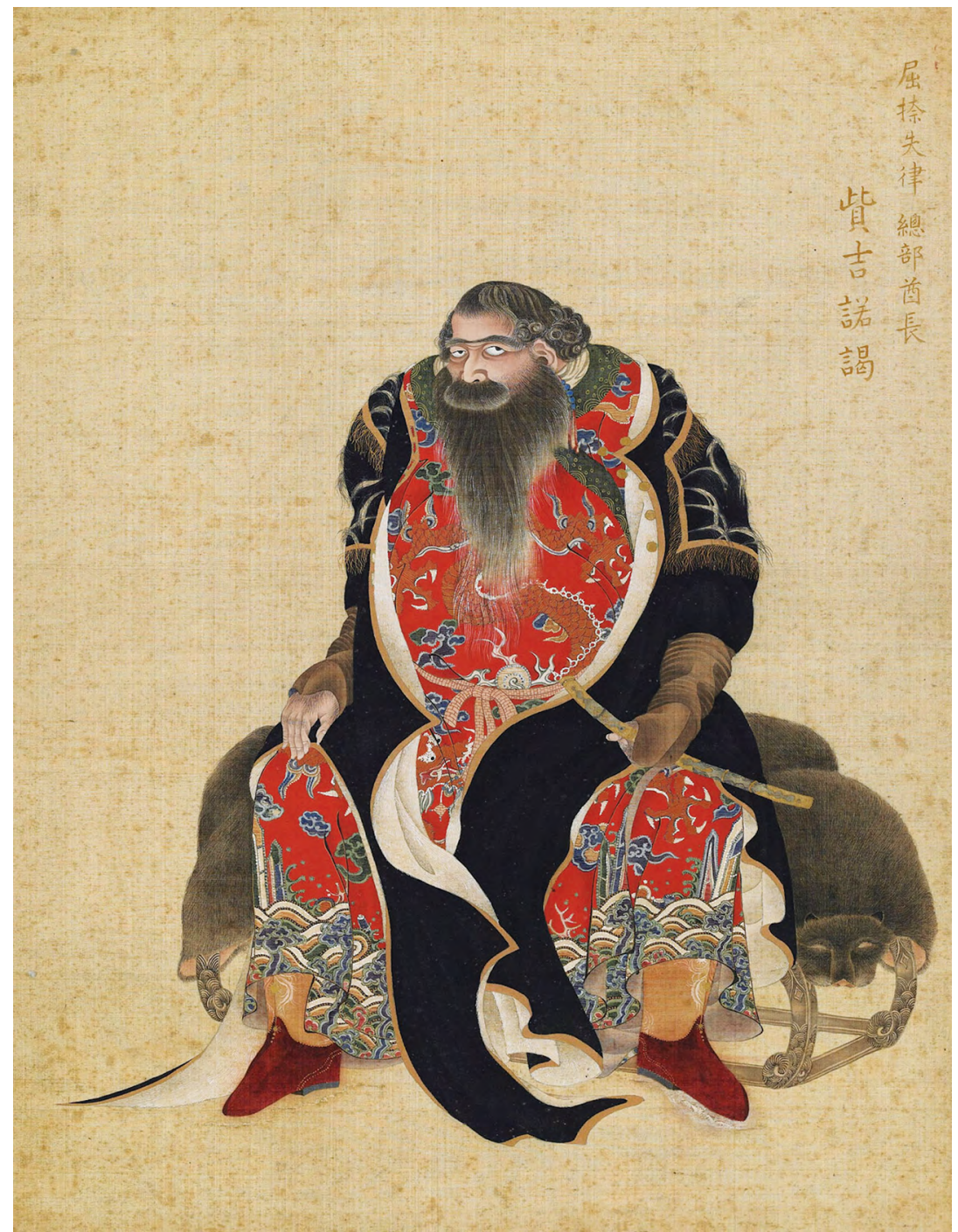

Figure 5.4. Tsukinoe, an Ainu elder from Kunashir, wearing a brocade robe, painting by Kakizaki Hakyo.

Source: Wikimedia commons, public domain. 
La Pérouse arrived in Sakhalin at a time when two other groups of people were also becoming increasingly visible in the Amur-Okhosk region. The Russian empire by now extended as far as the Kamchatka Peninsula and the northern Kurile Islands, but Russian settlement had not yet expanded to the mouth of the Amur or Sakhalin, though some Cossack adventurers had reached these regions in the seventeenth century. ${ }^{25}$ By the end of the eighteenth century, Imperial Russia was interested in commercial and strategic expansion to the east, and a series of expeditions were sent to Amur-Okhotsk. In 1791, Adam Laxman was commissioned to return two Japanese castaways to their homeland, and at the same time observed and brought back reports on Japan and Hokkaido to St Petersburg; 13 years later, Russian Admiral Adam von Krusenstern also visited Hokkaido and Sakhalin during his circumnavigation of the globe. Krusenstern borrowed much preliminary geographical knowledge from La Pérouse, but sought to revise and expand that knowledge with his own observations. Because he made contact with Japanese in northern Hokkaido and southern Sakhalin, and had an interpreter who spoke some Japanese, Krusenstern could identify the mountain peak off northern Hokkaido that La Pérouse had named De Langle Peak by its Japanised Ainu name, Rishiri (Krusenstern calls it 'Rii-schery'). ${ }^{26}$ In 1811, Russian navigator and cartographer Vasily Golovnin also arrived on Kunashir Island to map the southern Kurile and the northern coast of Hokkaido, but was captured by the Japanese and held as a prisoner for two years before being returned to Russia. The local inhabitants played an important role as intermediaries in these interactions between Russia and Japan. For example, when Golovnin first arrived on the island of Iturup in the southern Kuriles, he was able to gather substantial amounts of information from Ainu who came from the northern Kuriles and could speak Russian. One of them served as an interpreter in Golovnin's discussions with the Japanese officials he encountered on Iturup, translating Russian into Ainu, which was then retranslated into Japanese by one of the locally based Japanese officials. ${ }^{27}$

25 See, for example, GP Muller, Voyages et Découvertes Faites par les Russes le Long des Cötes de la Mer Glaciale et sur l'Ocean Oriental, tant vers le Japon que vers l'Amerique, trans. CGF Dumas, vol. 1 (Amsterdam: Marc-Michel Rey, 1766).

26 AJ von Krusenstern, Voyage Round the World in the Years 1803, 1804, 1805 and 1806, vol. 2 (London: John Murray, 1813), p. 48.

27 VM Golownin, Memoirs of a Captivity in Japan, ed. J McMaster, vol. 1 (Oxford: Oxford University Press, 1973). Here I have used the standard modern transliteration of Golovnin's name; see also Watanabe Kyōji, Kurofune Zenya: Roshia, Ainu, Nihon no Sangokushi (Tokyo: Yōsensha, 2010), pp. 292-93. 
Meanwhile, both the Japanese shogunate and Matsumae Domain were becoming increasingly aware of the presence of foreigners ('Red Ezo', as they were known, after the colour of their hair - Furesisam in Ainu) on the northern fringes of Japan. In the early 1780s, Kudō Heisuke, a Japanese doctor and scholar of Western learning had discovered, via information that trickled into Japan through the Dutch trading post in Nagasaki, that these foreigners were the people known as Russians, who belonged to a large empire stretching from Europe to Kamchatka. This prompted the shogunate to dispatch five officials to the northern regions in 1785 , to learn more about its inhabitants and particularly to discover the extent of foreign incursions. ${ }^{28}$ In the search for knowledge about Russians and other 'Red Ezo', Japanese explorers relied heavily on information from the indigenous people, particularly from the Ainu of the Kurile archipelago, who frequently encountered Russian settlers on Kamchatka and on the northern islands of the archipelago. The lords of Matsumae had sent officials to survey the south of Sakhalin as early as the 1630s, but the decades from the 1780s on were a time of particularly active Japanese exploration of the region. Scholar-officials Öishi Ippei and Mogami Tokunai were sent to explore the Kurile Islands and Sakhalin in 1786, and Mogami made many subsequent visits to the region. Nakamura Shōshirō and Takahashi Jidayū were sent to Sakhalin in 1801 to find out more about the island and its connections to the lands beyond. In 1808 Mamiya Rinzō and Matsuda Denjūrō made an extensive survey of the coast of Sakhalin, and the following year Mamiya travelled via Sakhalin to the Asian mainland and as far as the Amur trading post of Deren. ${ }^{29}$

French, Russian and Japanese explorers shared a number of common objectives. As Brett Walker observes, Japanese officials like Mamiya Rinzō and Matsuda Denjūrō saw Sakhalin with 'cartographic' and 'imperial' eyes. Mamiya in particular compiled intricate accounts of the indigenous peoples in which, like La Pérouse, he used careful description and comparison in an effort to define ethnic boundaries. ${ }^{30}$ But there are also some significant differences between the European and Japanese explorers, so their diverse but overlapping accounts of Sakhalin and the

28 Yoshida Tsunekichi, 'Kaisetsu', in Mogami, Ezo Sōshi, p. 269; see also Robert Liss, 'Frontier Tales: Tokugawa Japan in Translation', in Schaffer et al., Brokered World, pp. 1-47, reference from pp. 37-38. 29 See Mogami, Ezo Sōshi; Nakamura Shōshirō, 'Karafuto zakki', reprinted in Saisenkai Shiryō, ed. Takakura Shinichirō (Sapporo: Hokkaidō Shuppan Kikaku Sentā, 1982), pp. 599-650; Mamiya, 'Kita Ezo Zusetsu'; Walker, 'Mamiya Rinzō and the Japanese Exploration of Sakhalin Island'.

30 Walker, 'Mamiya Rinzō and the Japanese Exploration of Sakhalin Island', p. 299. 
Amur region offer some fascinatingly complementary images. La Pérouse arrived in large ships, with very little prior knowledge of the region. His first task was to find a safe place of anchorage, and this determined where he made landfall. Like most Western explorers of the day, he named natural features - bays, mountains, headlands - on his maps. Villages, although marked on the maps, are not given names. With rare exceptions, communication was conducted by sign language.

Conversely, Japanese explorers of Sakhalin in the same period travelled, usually in small boats, with Japanese-speaking Ainu or Nivkh guides and interpreters who led them from one village to the next. Their travel accounts are generally litanies of the names of villages, often including estimates of the distance between them. From their accounts we know that Tomarioro was a relatively small place - it is mentioned but rarely described in detail. By contrast, Nayoro, a little further north, was larger and also more politically significant. At some time around the middle of the eighteenth century, apparently after a conflict between locals and visitors from the mainland, two sons of a Nayoro Ainu elder had been captured by Manchus and taken to the mainland, where they lived for several years. Eventually they were allowed to return, and one was given an official Manchu document appointing him to the position of hala $i$ $d a$ or clan headman - the only Sakhalin islander to be awarded this rank. When Mogami Tokunai and Mamiya Rinzō visited Sakhalin, the position had passed to Yayenkur, a son of the original hala $i d a .^{31}$

After leaving Tomarioro, La Pérouse sailed up the west coast of Sakhalin until he reached another good anchorage, which he named D'Estin Bay. His description and measurements of latitude indicate that this was the Ainu village of Ushiyoro (or Ushoro), a larger settlement that also had close links to the mainland. Two of its villagers, Senbakur and Ikonaranke, had been given the Manchu title of gasan da or village chief (the rank below hala $i d a$ ). ${ }^{32}$ When La Pérouse arrived, he found a large canoe from the mainland just leaving after a trading visit. In Ushiyoro, Fleuriot de Langle, the captain of the Astrolabe, also described stakes surmounted by bears' heads - signs of the bear ceremony or iyomante, which was a vital element of the spiritual practice of Ainu, Nivkh and other indigenous groups of the region. ${ }^{33}$

31 See Mamiya, 'Kita Ezo Zusetsu’, pp. 116-17; Mogami, 'Ezo Sōshi Gohen', pp. 189-90.

32 Mamiya, 'Kita Ezo Zusetsu', p. 117.

33 La Pérouse, Journal, pp. 295-97. 
From Ushiyoro, the French expedition continued northwards, trying to determine whether there was indeed (as the Tomarioro elder had indicated) a navigable passage separating the entire length of Sakhalin Island from the Asian mainland. But the weather was worsening, and their depth soundings revealed the presence of dangerous shoals. At last, with evident disappointment, they were forced to turn back, and anchored in a bay to the south of the mouth of the Amur River, which they named De Castries Bay (now known as Kastri Bay). Here they found a village of people who, according to La Pérouse, called themselves 'Orotchys', and a boat with traders whom the 'Orotchys' called 'Bitchys, a name indicating that these people came from further south. ${ }^{34}$ La Pérouse describes the Orotchy as living by the coast for salmon fishing in the summer, but also having inland underground houses which they used during the winter months.

The area stretching southward from the mouth of the Amur was inhabited by a complex mixture of peoples, including the groups now known to ethnographers as Nivkh, Ul'chi, Nanai and Oroch. As the eminent Russian scholar Lev Shternberg was to discover in the late nineteenth century, attaching appropriate ethnic labels to these groups was a very difficult process. The Nivkh were relatively easy to identify, because they spoke a language quite distinct from that of other groups; but the groups now known as Ul'chi, Nanai and Oroch, as well as the Uilta of Sakhalin and a number of other Eastern Siberian groups, all spoke languages belonging to the so-called 'Tungusic' language family. As a result, the word that they used amongst themselves to designate their own group was more or less identical - 'Nani' (or a close variant), meaning 'people'. Each group also had a variety of terms that they used when describing their own group to outsiders, and when referring to neighbouring groups. It seems most likely that the people whom La Pérouse met belonged to the fishing and hunting group whom Shternberg calls the 'Oroch' or 'Southeastern Nani': when speaking amongst themselves they referred to themselves as 'Nani' or 'Nane', but when speaking to Russians (says Shternberg) they called themselves 'Orocha' or 'Orochon'. The term 'Bitchy' is probably Le Pérouse's rendering of the place name 'Botchy', which, according to Shternberg, was a village on the borderline between the regions of the northern and southern clans that constituted the Oroch/ Southeastern Nani. ${ }^{35}$

34 La Pérouse, Journal, p. 306.

35 L Ya Shternberg, Gilyaki, Orochi, Gol'diy Negidal'tsiy, Ainy (Moscow: Nauka reprint, 1991), pp. 6-9. 
At that time, as La Pérouse's account indicates, the Oroch people were an integral part of the complex trade networks that linked the AmurOkhotsk region via Manchuria to the Chinese empire:

grain was their most precious food; they told us that it came from the country of the Manchus and we verified that they gave this name only to the people who live seven or eight days' journey upriver on the Segalien and have direct contact with the Chinese. ${ }^{36}$

From the mid-nineteenth century on, though, their lives were to be drastically changed by Russian colonisation. (The 2010 Russian census gives a present-day Oroch population of just under 600 people. ${ }^{37}$ From conversations with the inhabitants of De Castries Bay, La Pérouse received what he thought was confirmation of the fact that the Tartar Straits to the north were impassable, because they were blocked by a shallow sandbank, thus justifying his decision to abandon the attempt to travel further north. ${ }^{38}$

Leaving De Castries Bay, the expedition returned to Sakhalin, and anchored on the west coast of its southern tip, which La Pérouse named Cape Crillon. The expedition's measurements of latitude suggest that their stopping point was just north of the Ainu village and port of Shiranushi (close to the spot on Sakhalin where the Dutch vessels Castricum and Breskens had landed over 140 years earlier). La Pérouse himself did not go ashore here, though he met local villagers who came out in small boats to meet his ship. His description makes it clear that these local people were Sakhalin Ainu, but he also noticed that they were more heavily influenced by Japan than the people of Tomarioro or Ushiyoro. ${ }^{39}$ Like the people of Tomarioro, though, these more southerly Ainu too had an intimate knowledge of the west coast of Sakhalin and the area around the mouth of the Amur. La Pérouse describes a map that they drew for him:

they traced the part we had visited up to the Segalien River, leaving a relatively narrow pass for their canoes. They marked each resting place and gave it its name; in the end one cannot doubt that although distant from the mouth of the river by more than 150 leagues they all knew it perfectly well.$^{40}$

36 La Pérouse, Journal, p. 306.

37 'Natsional'nyi Sostav Haseleniya Rossiisckoi Federatsii', 2010, available online at www.perepis-

2010.ru/results_of_the_census/tab5.xls (accessed 19 May 2013).

38 La Pérouse, Journal, pp. 312-13.

39 La Pérouse, Journal, p. 320.

40 La Pérouse, Journal, p. 321. 
The Astrolabe and the Boussole then rounded the cape at the southern tip of Sakhalin, sailed through the straits between Sakhalin and Hokkaido, and turned northwards, tracking alongside the Kurile Islands. La Pérouse had intended to land on one of these islands, but was deterred by persistent fog, and so sailed on the Kamchatka Peninsula, where he landed on 6 September 1787. There he entrusted the precious journals and sketches from his voyage to diplomat and Russian-language speaker Barthélemy de Lesseps, who took them back to France, thus (as it turned out) saving them from destruction on the reefs of the South Pacific.

\section{The Sandbank: Inscribing Scientific Mistakes}

Bruno Latour traces the process by which knowledge, and thus power, accumulate in the metropolises of modern Europe. Each expedition incorporates information brought back by the last, and therefore arrives in distant lands forearmed with ever more sophisticated knowledge. But, as Latour himself recognises, the knowledge brought back by Western explorers was quite often wrong. In the long run mistakes were gradually removed: as one expedition tried to replicate or improve on earlier voyages of discovery, each deepened and refined knowledge, just as Krusenstern elaborated on the knowledge brought back by La Pérouse. In the short to medium term, though, the mistakes incorporated into explorers' maps of the world could have significant results. While much has been written about the way in which Enlightenment scholars revealed scientific truths, less has been written about the process by which they made mistakes. La Pérouse's exploration of the Amur-Okhotsk region provides one particularly interesting illustration of this process, which is worth tracing in some detail.

One of the main objectives of this part of the voyage was to discover whether Sakhalin was an island, and whether it was possible to sail between it and the Asian mainland, thus potentially opening up an alternative route to the Kamchatka Peninsula. La Pérouse, as we have seen, was told by the Tomarioro villagers that such a route existed and attempted to follow it, but was forced back by bad weather at the narrowest point between the island and mainland. When the expedition reached De Castries Bay, as La Pérouse reports:

We used all our skill to question [the 'Bitchys'] on the country's geography; we drew the coast of Tartary with a pencil on some paper, with the Segalien River and the island of the same name 
facing it ... and we left a pass between them; they took the pencil from our hands and joined by a line the island and the mainland, then pushing their canoe over the sand they explained that, after leaving the river, they had pushed their boat in this manner on the sandbank which joins the island to the mainland they had just drawn; after which, pulling up some weeds from the bottom of the sea ... they planted it on the sand to make clear that the sandbank they had crossed is also covered with seaweed. ${ }^{41}$

Just as vividly as the mapping incident in Tomarioro, this story shows the local familiarity with mapping processes, and also the remarkable extent to which two groups of people with no language in common were able to communicate by sign language. In this case, though, La Pérouse's interpretation of the sign language turns out to have been mistaken. He was puzzled by the discrepancy between the account of the Tomarioro villagers, who had informed him that the straits were passable, and that of the De Castries Bay people, who seemed to be saying that they were blocked by a sandbank that they could cross on foot. He had been intending to send a longboat to try once again to find a passage northward, but was anxious about the possible dangers and also eager to reach Kamchatka before winter - 'we did not have a moment to lose' - so, after further questions failed to produce any more information from the local people, he decided to reconcile the two stories by assuming that there was a weedcovered sandbank across the straits with narrow channels which could be navigated by canoe but not by ship. ${ }^{42}$

When Japanese explorer Mamiya Rinzo visited the region two decades later, he was able both to spend longer in northern Sakhalin and the Amur and to have conversations with local people via an interpreter. He therefore discovered a fact that surely explains the message the De Castries Bay villagers tried so hard to communicate to La Pérouse with their canoes and bunches of seaweed:

because the width of the strait averages only fifteen to twenty-four miles and at the narrowest only five to seven miles, there is a rapid mid-stream current as violent as a river in flood. The tide ebbs so greatly that at low tide the bottom of the sea lies bare for a distance of two to five miles, and as far as one can see, there are acres of blue-green seaweed producing a sight which simply cannot be illustrated and which is never seen in Japan. ${ }^{43}$

41 La Pérouse, Journal, pp. 312-13.

42 La Pérouse, Journal, p. 314.

43 Mamiya, 'Kita Ezo Zusetsu', p. 99. 


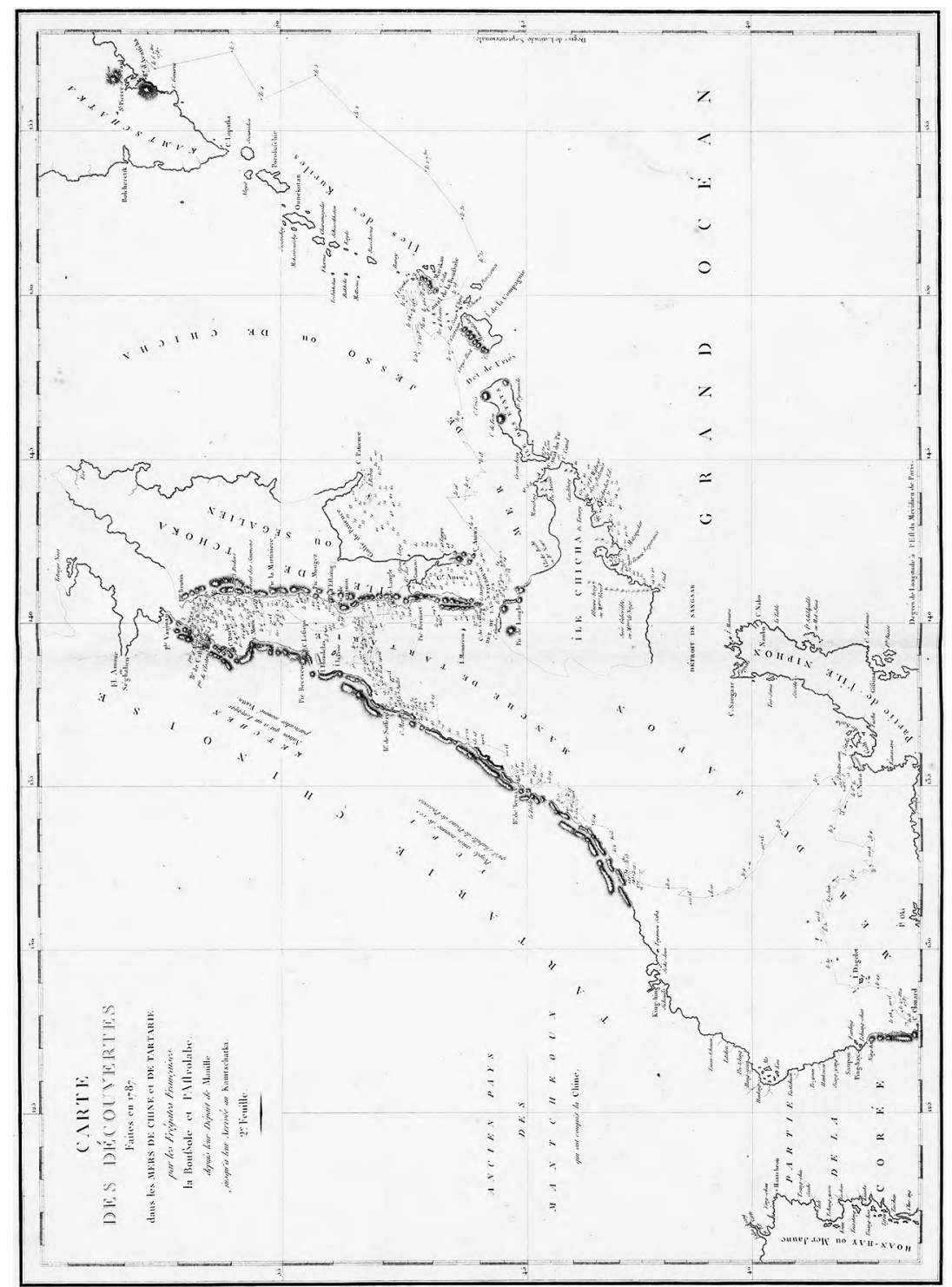

Figure 5.5. La Pérouse's map of Sakhalin.

Source: Jean-François de Galaup La Pérouse, 'Chart of the Discoveries Made in 1787, in the Seas of China and Tartary, by the Boussole and Astrolabe', Sheet II (London: G.G. and J. Robinson, 1799). David Rumsey Collection, List no. 0414.046, reproduced with kind permission of the David Rumsey Collection (www.davidrumsey.com). 
In other words, the narrow neck of the straits, though dangerous, was deep enough to be navigable, but at low tide it was bordered on either side by wide, kelp-covered stretches of sand over which anyone trying to cross the straits had to drag their canoe. This was of crucial importance to the Oroch and other people of the region, for whom the narrows was a crossing point between the mainland and Sakhalin; but was at crosspurposes to La Pérouse's question, since he was interested, not in how to cross the straits, but rather how to sail through them. The readiness with which La Pérouse interpreted the villagers' sign language as meaning that the straits were impassable may in part have reflected his own anxiety to justify his decision to turn back rather than attempting to press on northwards against the odds.

In any event, the result was that the impassable sandbank La Pérouse believed he had been told about was carefully and scientifically inscribed on the map of the region, and remained on many maps until the middle of the nineteenth century. Almost 80 years later, during the Crimean War, a British naval squadron pursued their Russian opponents up the straits between Sakhalin and the mainland, but then abandoned the pursuit and waited in vain to ambush the Russians as they returned southwards, believing (on the basis of La Pérouse's cartography) that there was no means of escape to the north. But the Russians never returned: having learnt their geography from Mamiya Rinzō and others, they had sailed right through the straits, around the northern tip of Sakhalin and out into the Okhotsk Sea. ${ }^{44}$

The incident is a small one, but it illustrates a significant point. It was the very scientific quality of La Pérouse's research - the capacity for his illusory sandbank to be drawn by European cartographers in such persuasive technical detail - that allowed the mistake to persist for so long. The power of Enlightenment science lies in its ability to abstract and schematise, creating knowledge in forms that can be superimposed and combined into one great knowledge system. But its potential weakness lies in the fact that, through this process of abstraction, the fine-grained detail may be lost. This weakness is compounded by the very authority of the scientific inscription, which discourages the modesty that might generate (sometimes very necessary) doubt, self-questioning and acknowledgement of ambiguity.

44 FA Golder, Russian Expansion on the Pacific, 1641-1850 (Cleveland: Arthur H. Clark and Co., 1914), pp. 264-65. 


\section{The Tinderbox: Observing the Observers}

By following the voyage of La Pérouse through the Amur-Okhotsk region, we can gain insight into the Enlightenment process of observing and gathering knowledge from the field. But an exclusive focus on the ways in which European explorers perceived and extracted knowledge from local people can obscure the other side of the story: it easy to forget that the observers were also being observed.

Japanese scholar Mogami Tokunai first visited the west coast of Sakhalin in 1792, five years after La Pérouse's arrival on the same shores. By this time Mogami had already made three journeys through Hokkaido and the Kurile Islands, compiling information that was later published under the title Ezo Söshi [Notes on Ezo]. It was on his 1792 visit, though, that the Ainu inhabitants of a village called Shōni, about 7 miles north of Shiranushi, told him a story about the coming of a ship belonging to Red People (Russians or other Europeans). In an appendix to Ezo Söshi completed in 1800, Mogami retells the story as follows:

During the Tenmei Era (1781-1788) a ship of Red People came to Karafuto (Sakhalin) and stopped at a place called Shōni, three $r i$ north of Shiranushi. It was the first time those Ainu had seen a foreign [i.e. European] ship, so they were all frightened. [The foreigners] sent out a boat which landed on the shore, and summoned the Ainu, but they were reluctant to approach. At last, many Ainu gathered, and they [the foreigners] measured the Ainu from head to foot, and furthermore cut off a little of their hair with a small sword. The Ainu were absolutely astonished and alarmed, but they wanted to be helpful, so they stayed still. Then the Red People brought out an implement about two $\operatorname{sun}^{45}$ in length, and made of brass. Inside it, the Ainu could see something that looked like the head of a snake. They were pressed to accept it as a present, but they refused. Then the part like the head of a snake moved, and produced a flash of fire and smoke. The Ainu people still tell the story of how fearful it was. ${ }^{46}$ 
Some Japanese commentaries on Mogami explain this as being a reference to the arrival of an anonymous Russian vessel, ${ }^{47}$ but as Akizuki Toshiyuki has suggested, it must surely be a rare description of the La Pérouse voyage from the side of the people whom the French explorer studied: to be precise, from the perspective of a village close to the point that he called Cape Crillon. ${ }^{48}$ The account of the measuring of bodies is too vivid and realistic to have been invented, since neither Ainu nor Japanese were at that time familiar with anthropometric ethnography. Japanese scholars such as Mamiya Rinzō certainly observed, drew and described the appearance of the various groups of people they met on their travels, but they did not measure them or remove samples of their hair. Such techniques would not be introduced into Japanese scholarship until the late nineteenth century. There is no evidence of any Russian scientific expedition to Sakhalin in the 1780s that might have undertaken scientific studies of the physique of the local people; but La Pérouse's expedition did carry out anthropometric research.

In his journal, La Pérouse writes that the Tomarioro villagers 'allowed our artists to draw them, but constantly declined the requests of Mr Rollin, our surgeon, who wanted to take measurements of their bodies' ${ }^{49}$ He makes no other mention of body measuring; but Rollin wrote his own separate account of the native people of Sakhalin and at De Castries Bay, and from this it is clear that he did succeed in measuring the bodies of both groups. He ends his description with a table giving comparative measurements of the inhabitants of the 'Island of Tschoka' (Sakhalin) and De Castries Bay, including such details as 'length of the upper extremities', 'ditto of the feet', 'circumference of the breast' and 'circumference of the pelvis' ${ }^{50}$ His detailed account of the Sakhalin islanders' physique includes the comment that:

the hair of the head is generally black, smooth and moderately strong; but in some it is chestnut; they wear it round, about six inches long behind, and cut into a brush on the forehead and temples. ${ }^{51}$

47 See, for example, Yoshida Tsunekichi's postscript to Mogami Tokunai's Ezo Sōshi and 'Ezo Sōshi Gohen', pp. 225 and 227.

48 Akizuki, Nichirō Kankei to Saharintō, p. 41.

49 La Pérouse, Journal, p. 292.

50 Rollin (La Pérouse's surgeon), 'Dissertation on the Natives of Tschoka Island, and on the Eastern Tartars, by Mr. Rollin MD', in La Pérouse, Voyage, pp. 381-90, quotation from p. 390.

51 Rollin, 'Dissertation on the Natives of Tschoka Island', p. 382. 
We can also tell from this account that Rollin went ashore at Cape Crillon, for he gives a detailed description of the 'habitations on the south of the island', which, he says are 'built with more care' than those further north (in Tomarioro and Ushiyoro), and he writes that:

we observed in some of them vessels of Japanese porcelain, which the great value set on them by the owners led me to believe were not to be procured without considerable expense. ${ }^{52}$

Rollin's measurements of Ainu must have been carried out either near Cape Crillon or in Ushiyoro, or in both places.

The brass object that caused the people of Shōni such alarm sounds very much like an eighteenth European tinderbox: these commonly contained a serpentine-shaped metal hand-piece for striking sparks. The gifts for natives carried on the Astrolabe and Boussole included 1,000 'steels for striking fire..$^{33}$ What is a little puzzling, though, is the terror this induced in the Ainu observers. Sakhalin Ainu were familiar with tinderboxes. La Pérouse's journal itself notes that the Tomarioro villagers had tinderboxes that 'came from the country of the Manchus' ${ }^{54}$ These, although different in design from the European versions, would have operated similarly. The object described in Mogami's account seems altogether more novel and spectacular - something closer, perhaps, to a recent and still experimental innovation that was also in the inventory of the Astrolabe and the Boussole: phosphorous matches. ${ }^{55}$

The story of the Shōni villagers is not, of course, an authentic eyewitness Ainu account of the coming of Western explorers: it has been filtered through the process of retelling to and by a Japanese official. It is, though, an eloquent reminder of the fact that the actions of explorers and other foreign travellers were observed, remembered, communicated over distances and, in some cases, avidly recorded and 'brought back' by both by Ainu and other people of Sakhalin and by Japanese scholars, who used them to build their own images of the world.

52 Rollin, 'Dissertation on the Natives of Tschoka Island', p. 383.

53 La Pérouse, Voyage, p. 183.

54 La Pérouse, Journal, p. 289.

55 La Pérouse, Voyage, p. 188. 


\section{Overlapping Geographies, Intersecting Ethnographies}

'Modernity' tends to be envisaged as a great wave spreading outwards from Western Europe, carrying with it a burden of memories and desires that it deposits on every shore it touches. Some see the wave as the water of life that bears the floating seeds of rationality, freedom and human dignity; to others it is an annihilating flood, its arrogant, Eurocentric certainties sweeping away the variety and vitality of indigenous life. But neither simple image does justice to the complexity of the forces and traditions of thought that came together in the making of the modern world. The fate of the people of the Amur-Okhotsk region came to depend, not just on ideas of civilisation and progress accumulated and refined in Europe, but also on the confluence of those ideas with the shifting images of the world created by many non-state societies (such as those of the Ainu, Nivkh, Uilta and Oroch) and by a multitude of states (including China and Japan).
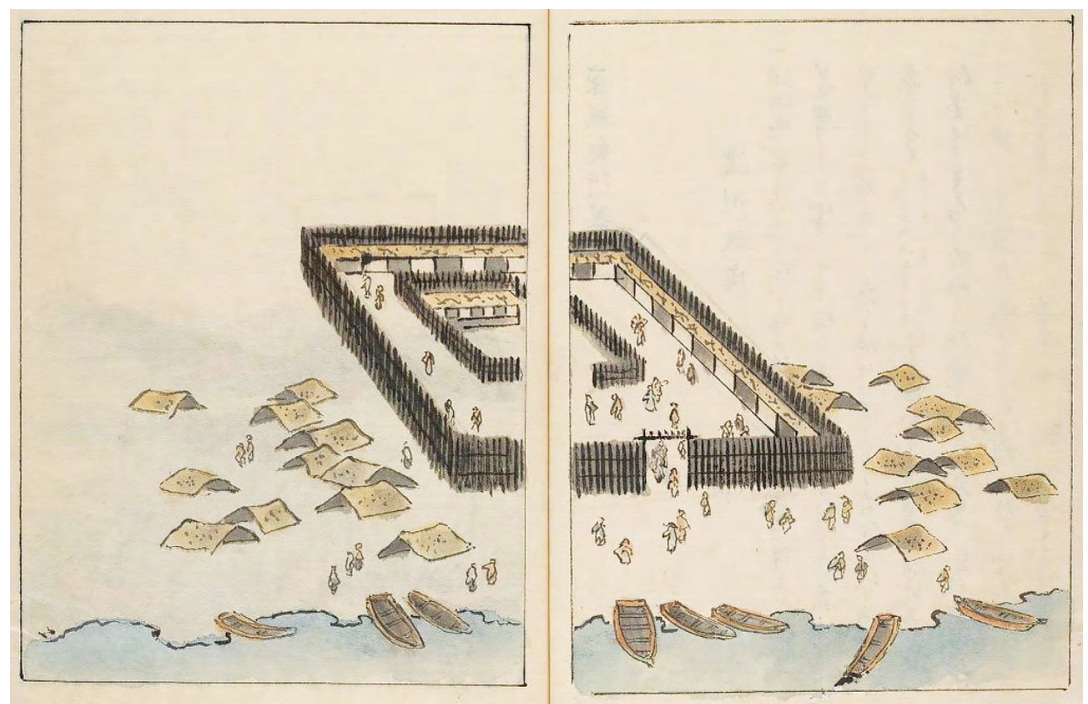

Figure 5.6. The trading post at Deren.

Source: Mamiya Rinzō, Tōdatsu Kikō (Dairen: Minami Manshū Tetsudō Kabushiki Kaisha, 1938) (original written in 1810 and first published in 1911), vol. 2. 
When Japanese explorer Mamiya Rinzō arrived at Deren on the Amur River in the summer of 1809 , he found a place whose modest appearance belied its cultural importance. It consisted only of a wooden palisade surrounding a single official building and an array of makeshift trading stalls. In winter the place was deserted, and on summer nights the candlelit palisade shone dimly in the wide darkness of surrounding forest. But by daytime in summer, Deren was transformed. Qing officials, who arrived in spring and left in the autumn, slept in junks moored in the river, while several hundred representatives of the neighbouring Ainu, Nivkh, Ul'chi, Oroch and other societies camped in small bark shelters around the outside of the palisade. ${ }^{56}$ Once they arrived in Deren, the tribute-bearers began by making a ceremonial visit to the junk of one of the chief officials. Then, a couple of days later, they entered the palisade bearing their tribute of furs, and waited until a minor official summoned them into the central hall. Here stood a dais, on which the representatives of Qing authority sat in a row, raised to an appropriate height above the heads of their vassals. The tribute-bearers knelt before the officials to present their gifts of sable, bowed three times to the ground, and were then rewarded with bolts of silk or other gifts from the dais.

Despite all the rigidity of its formal etiquette, Deren was a centre of thriving social interaction. The senior Qing tribute collectors were (like the emperors themselves) Manchus, but the 50 or so minor officials who helped to run the trading post were drawn from many societies, including the local Nivkh, Ul'chi and Nanai language groups. Once formalities were over, minor officials and tribute-bearers mingled around fringes of the palisade, trading goods, exchanging news, arguing, greeting old friends or long-lost relatives, playing with one another's children. ${ }^{57}$ The Qing emperors prevented Han Chinese migration to their own original homeland, Manchuria, and left local Manchu officials to control the relationship between the many peoples on the north-eastern fringes of the empire. From the official perspective, the formalities that took place at Deren were an act of submission by the 'barbarian' peoples of the north-east to the Chinese imperial centre. Sakhalin Ainu who had been appointed to the position of hala $i$ da or gasan $d a$ were required to

56 Mamiya Rinzō, Tōdatsu Kikō (Dairen: Minami Manshū Tetsudō Kabushiki Kaisha, 1938), pp. 31-38. Original written in 1810 and first published in 1911.

57 Mamiya, Tödatsu Kikō, pp. 40-43. 
travel to Deren regularly every one or two years to pay tribute. ${ }^{58}$ From the perspective of the Ainu and other local peoples, though, visits to Deren were very probably seen more as profitable trading opportunities than as acts of political homage to the distant Chinese emperor.

Through their partial incorporation into the fringes of the Chinese empire, the people of the Amur-Okhotsk region came into closer contact both with one another and with long-standing Chinese systems for classifying the peoples of the known world, and these encounters undoubtedly exerted an influence of the ways in which they defined their own place in that world. From ancient times, Chinese scholars had attempted to describe and categorise the people to the far north-east of the empire, placing them in the order that defined the relationship between civilised centre ( $h u a$ ) and barbarian periphery (i). Late Ming Dynasty studies had produced a relatively detailed classification of the people of Lower Amur, including references to a group known as the 'Kuwu', generally believed to be Sakhalin Ainu. ${ }^{59}$ When La Pérouse attempted his ethnographic mapping of the region, then, he was encountering people whose self-identification was not naïve and instinctive, but had already been influenced by encounters with the ethnographic schemas of others.

The Chinese passion for classifying and ordering the world is also reflected in the ethnographies compiled by Japanese explorers like Mamiya Rinzō. Though Mamiya had encountered some elements of Western scientific knowledge both via the Dutch and via the Russians, his conceptual framework remained much closer to that of Chinese descriptions of the empire's 'barbarian fringe'. He aimed to reorient the political and geographical order by placing Japan, rather than China, at the centre. But his ability to converse with the people of Sakhalin and the Amur via interpreters also enabled him to provide a richly detailed account of the appearance, customs and material life of the people he met on his travels.

58 Mamiya, 'Kita Ezo Zusetsu', p. 117.

59 See Sei Wada, 'The Natives of the Lower Reaches of the Amur River as Represented in Chinese Records', Memoirs of the Research Department of the Toyo Bunko 10 (1938): pp. 40-102, particularly p. 81; also Sasaki Shirō, 'Amūru-gawa Shimoryūiki Shominzoku no Shakai, Bunka ni okeru Shinchō Shihai no Eikyō ni tsuite', Kokuritsu Minzoku Hakubutsukan Kenkyū Hōkoku 14, no. 3 (1989): pp. 671-771; Matsuura Shigeru, Shichō no Amüru Seisaku to Shosū Minzoku (Kyoto: Kyoto Daigaku Shuppankai, 2006). 


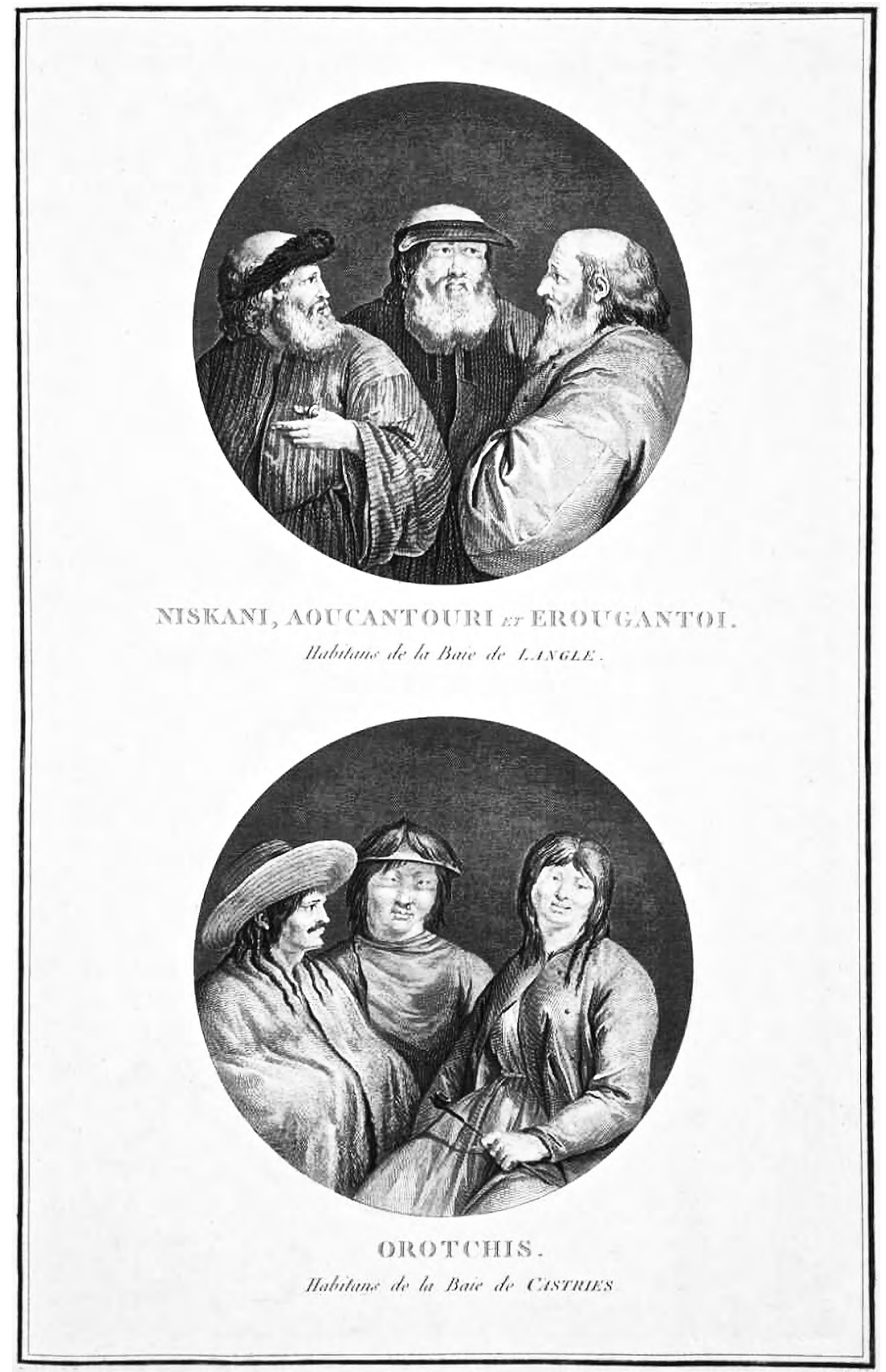

Figure 5.7. Portraits of Sakhalin Ainu 'Niskani, Aoucanouri and Erougantoi' of Tomarioro.

Source: Illustration by JBB Simonet, from Jean-François de Galaup de La Pérouse, Atlas du Voyage de La Pérouse autour du Monde (Paris: 1797). 
He tells us how the Sakhalin Ainu catch sable, and how they feed their dogs (which are treated 'as though they are children'); how their blacksmiths forge metal using bellows made of fish-skin; how Uilta herd reindeer and how Ainu and Nivkh conduct funerals; and so on. ${ }^{60}$ The illustrations to his works, which depict indigenous groups in the traditions of Japanese popular painting, draw on the experience of his prolonged stays in Sakhalin. He can draw Ainu, Nivkh and others engaged in a range of everyday tasks - fishing, nursing children, combing their hair, etc. By contrast, the visual images from La Pérouse's expedition, reproduced in a style strongly influenced by European classical images of beauty, focus on the moment of encounter between Europeans and locals (though the French explorers were unusual in attempting to produce portraits on named individuals whom they met on their travels).

Meanwhile, Ainu and other people of the Amur-Okhotsk region gathered their own knowledge of and from the peoples they encountered in their travels. Although there were as yet no Japanese settlers in Tomarioro, for example, the Ainu vocabulary assembled by La Pérouse shows that the villagers were familiar with guns, for which they used the Japanese loan word tai-po. ${ }^{61}$ Their knowledge of neighbouring regions in turn was eagerly sought by Japanese scholars and explorers, as they tried to piece together a picture of the world beyond their northern and western horizons. Nakamura Shōshirō used information from local informants in Sakhalin to sketch the geography of north-eastern Manchuria, including places as far distant as the Manchu city of Ice Hoton (present-day Yilan in Northeast China) and to describe recent events (such as a famine and epidemic) in that region. ${ }^{62}$ Mamiya Rinzō, who was unable to reach the far northern part of Sakhalin, described and mapped this part of the island on the basis of information given to him by the Ainu and Nivkh whom he met. These descriptions, too, are vivid and detailed (though he concludes them with the disclaimer that 'these above paragraphs have been set down by Rinzō from what the natives told him, so they may contain mistakes'). ${ }^{63}$ For example, of the north-western stretch of Sakhalin coast facing the mouth of the Amur, his local informants told him that:

the water of the sea is less salty and as it is supplied by the tides of the northern sea there are ample trout, salmon and other fish upon which the [Ainu] feed, which makes for a numerous

60 Mamiya, 'Kita Ezo Zusetsu'.

61 La Pérouse, Journal, p. 341.

62 Nakamura Shōshirō, 'Karafuto Zakki'.

63 Mamiya, 'Kita Ezo Zusetsu', p. 101. 
population. The number of Orokko [Uilta] and Sumerenkur [Nivkh] communities is about thirty-four or thirty-five. Three of these are especially large, each containing several dozen hamlets. ${ }^{64}$

Ainu informants also played a crucial role in enabling Japanese explorers to gather information about the Russians in the eastern Okhotsk region. Mogami Tokunai's descriptions of the Russians, which he gathered in the Kurile Islands, relied on the help of two Ainu, Haushibe and his younger brother Ivanushka. While Haushibe was an elder of the local Ainu community, Ivanushka had been converted to Christianity through his contact with Russian traders and settlers in the islands, and became a Russian interpreter, one of a quite substantial group of Ainu who acted as intermediaries in the earliest interactions between Japanese and Russians. ${ }^{65}$

The geographical and ethnographic information about the Amur-Okhotsk region compiled by Mogami, Mamiya and others was then eagerly consumed by early nineteenth-century European scholars and explorers. The German doctor Philipp Franz von Siebold, who was employed by the Dutch East India Company in their trading post in Nagasaki, managed to obtain a copy of Mamiya's account of Sakhalin and the Amur, and incorporated a translation of it into his monumental work Nippon, first published in $1832 .{ }^{66}$ Conversely, Japanese scholars were busy translating European works such as Krusenstern's account of his voyage through the Okhotsk Sea, which they had obtained from Siebold in an unauthorised exchange of knowledge that attracted the wrath of the shogunate. ${ }^{67}$

\section{Knowledge and Modernity in the Okhotsk Region}

All of this suggests something more complex than a vortex that ceaselessly draws knowledge and power into the metropolitan centres of Enlightenment Europe. It is, of course, true that emerging European methods of representing and ordering global geography and ethnography made it possible to accumulate knowledge on an unprecedented scale,

64 Mamiya, 'Kita Ezo Zusetsu', p. 100.

65 See Shimaya Ryōkichi, Mogami Tokunai (Tokyo: Furukawa Kobunkan, 1977), pp. 36-37.

66 Phillipp Franz von Siebold, Nippon: Archiv zur Beschreibung von Japan, vol. 2 (Würzberg and Leipzig, Verlag der K U K Hofbuchhandlung von Leo Woerl, 1897), pp. 207-69.

67 Donald Keene, The Japanese Discovery of Europe, 1720-1830, rev. ed. (Stanford: Stanford University Press, 1969), p. 149. 
but it is also important to acknowledge that the accumulation of modern knowledge was a very complex and multidirectional process, in which non-European centres including Japan and even small indigenous societies played a role, not just as sources but also as gatherers of knowledge.

This points to a need to rethink the relationship between knowledge and power. By the late nineteenth century, the small Ainu, Nivkh, Uilta, Oroch and other communities of the region found their lives overturned by the massive impact of the modern colonial world. But the role of science in the transformation of power relations was complicated and mediated by many other factors. The forces that devastated their traditional ways of life were less those of mechanised modern technology than forces of the epidemic diseases spread by settler communities, and of environmental destruction unleashed by Russian convict exiles and Japanese immigrant farmers. Colonial modernity, rather than making immobile 'natives' mobile, carved national frontiers through the Amur-Okhotsk region, severing trade routes and constricting the social horizons of the local people. In the next two chapters, we shall look more closely at the way in which these national frontiers were drawn, and how the indigenous people of the region responded and adapted to their presence.

Visiting Tomarioro in 1787, La Pérouse described the 21 villagers he met there as having 'more politeness, more gentleness, more seriousness and maybe a greater intelligence than any nation of Europe', and predicted that although 'they are a very well governed people, [they] are so poor that they will not for many years attract the cupidity of conquerors or traders' ${ }^{68}$ His prediction proved mistaken, but his arrival on the eve of the coming of conquerors provides a precious opportunity to explore the interweaving of many forms of knowledge that helped to form the complex texture of the modern world.

This chapter is a slightly revised version of an article that first appeared in the journal East Asian History 39 (2014): pp. 33-52. 
This text is taken from On the Frontiers of History: Rethinking East Asian Borders, by Tessa Morris-Suzuki, published 2020 by ANU Press, The Australian National University, Canberra, Australia.

doi.org/10.22459/OFH.2020.05 